\title{
Metacognitive Strategies to Train Creative Thinking Skills in Creating Media for Learning
}

\author{
Merina Safitri, Sunu Kuntjoro \\ Post Graduate, Universitas Negeri Surabaya, \\ INDONESIA \\ merinasafitri16070795027@mhs.unesa.ac.id, \\ sunukuntjoro@unesa.ac.id
}

\author{
Endang Susantini \\ Biology Department, Universitas Negeri Surabaya, \\ INDONESIA \\ endangsusantini@unesa.ac.id
}

\begin{abstract}
Students' creative thinking skill is still found to be low. One strategy to train creative thinking skill is metacognitive strategies. In this strategy, students are trained to monitor their own thinking to come up with ideas to solve problem of creating a work. This study aims to train students' creative thinking skills through metacognitive strategies. Aspect to be measured is skill in creating learning media on the material of coordinate system. This research uses pre-experimental design with one-shot case study which involves 23 Senior High School students of grade XI. Data analysis technique uses descriptive analysis of quantitative and qualitative. Findings indicate that students can create learning media coordination system in the form of a poster, a game of monopoly, and 3D media with creative after experiencing learning with metacognitive strategies. The average score of students' creative thinking skill on aspect of originality is 84.75 with a very unique category and falls to creative thinking with very high criteria. Learning on metacognitive strategiesbased coordination system is able to train students' creative thinking skills in making learning media.
\end{abstract}

Keywords- Coordination system, Creative thinking, Learning media, Metacognitive strategy.

\section{INTRODUCTION}

One of highly problematic issues in education is the lack of creative thinking skills of students that they are not able to meet educational challenges of $21^{\text {st }}$ century that demands a superior generation to have creative thinking skills [1]. Creative thinking is one of the high-level thinking skills that can help students create new ideas based on knowledge that has been held to resolve the problems of a different viewpoint, as well as to discover new innovations in human life. From the research found in biology class, students' creative thinking skill is still low, especially in the difficult materials that demands low creative thinking skills [6]. One of biology materials difficult to understand is coordination system. This is indicated by the results of test related to coordination system. In such, students just merely memorize the materials that they find difficult, showed by low score of test [4].

One of the learning strategies that can help improve students' creative thinking skills is metacognitive strategy. Metacognitive strategy plays an important role in the success of students' learning because it can improve learning outcomes and develop characters such as honesty and responsibility [11]. Metacognitive strategy makes students more successful because it can help them to direct their own learning [7]. Furthermore, Hargrove [3] stated that using some metacognitive strategies can help develop students' thinking skills, build metacognitive skills and their creative thinking. Metacognitive strategy can be used to teach Learning Strategy (LS) so that students can broaden their LS understanding and thus enable to choose LS which fits to them [10]. Ibe [5] added that metacognitive strategies in learning can motivate students to improve their learning awareness, provide an opportunity to learn how to understand and solve problems, and cultivate their creative thinking skills. Search Solve Create and Share Learning with integrated learning Metacognitive Strategy [SSCS + MS] has the potential to improve the skills of creative thinking of students with low academic skill, and has the potential for improving students to be equal with students of high academic skill [12].

There are four metacognitive strategies that can be used in learning, namely, self-planning, self-monitoring, selfmodifying, and self-evaluating. Self-planning is the estimated time required to complete the task of learning, making learning time plan so as to take steps which corresponds to mind mapping. Also, it can train thinking skill of originality, i.e creating a unique idea for original work $[8,9]$

From several studies it can be concluded that metacognitive strategies in learning can improve students' creative thinking skill. Therefore, it is necessary to train creative thinking skills of high school students, especially on the subjects of biology of coordinate system based on metacognitive strategies through the creation of coordination system- based learning media by students.

\section{METHOD}

Pre-experimental design with one-shot case study was tested on 23 students of grade XI Sehior High School of Ulul Albab. This is as follows [2]: 


\section{$\begin{array}{cc}\mathbf{X} & \mathbf{O} \\ \text { Treatment of independent } & \text { Observation or measurement }\end{array}$ variables}

Data were analyzed using descriptive analysis of quantitative and qualitative. Quantitative descriptive analysis is used to measure creative thinking skills. Descriptive qualitative analysis is used to describe observations of instructional material based coordinate system of metacognitive strategies to train the creative thinking of students in making learning media.

In this research, creative thinking measured is originality. The students create a unique idea by making learning media about coordination system in a group by using metacognitive strategies of self-planning. Students are categorized as being able to think creatively when their score is at least 61.2. Criteria of creative thinking skills in detail is shown in Table 1 below:

TABLE I. CRITERIA OF CREATIVE THINKING SKILLS LEVEL [9]

\begin{tabular}{|c|c|}
\hline Percentage (\%) & criteria \\
\hline $81-100$ & Very High \\
\hline $61-80$ & High \\
\hline $40-59$ & sufficient \\
\hline $20-39$ & low \\
\hline $0-19$ & Very Low \\
\hline
\end{tabular}

\section{RESULTS}

Learning media made by group I is in the form of a poster of the human nervous system. The nervous system poster made by students is two-dimensional in shape using the paste technique from the results of the printed image and writing cut outs shown in Figure 1 below.

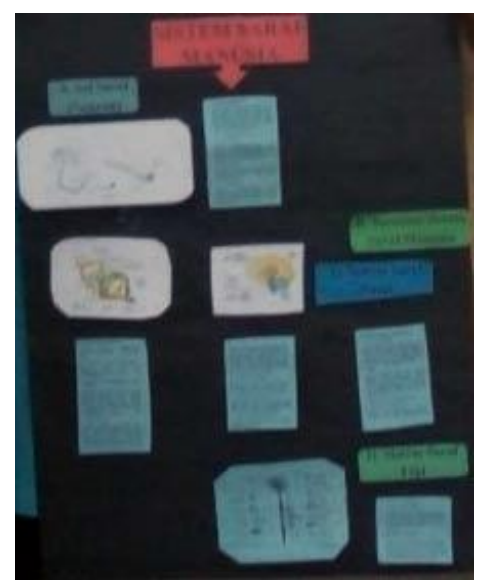

Figure 1: 2D Poster Learning Media of Nervous System Group I

Learning media made by group II is in the form of $3 \mathrm{D}$ media which is used in playground, having theme of hormone system sub-material shown in Figure 2.

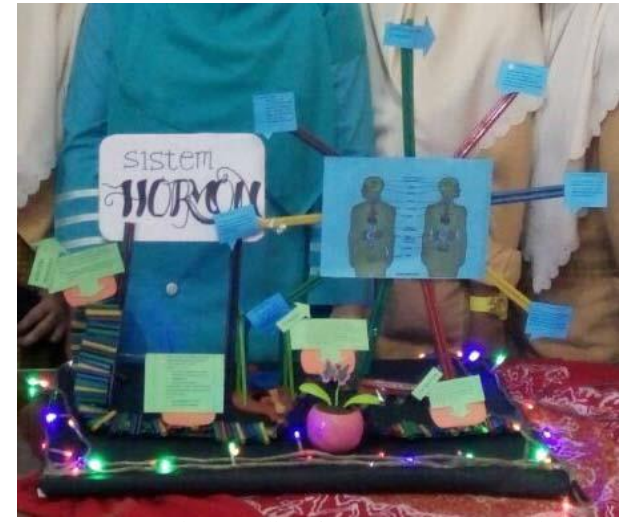

Figure 2: 3D Learning Media of Hormone Systems by Group II

Learning media made by the group III uses game theme in the form of monopoly on the material of senses (eyes and ears) as shown in Figure 3.

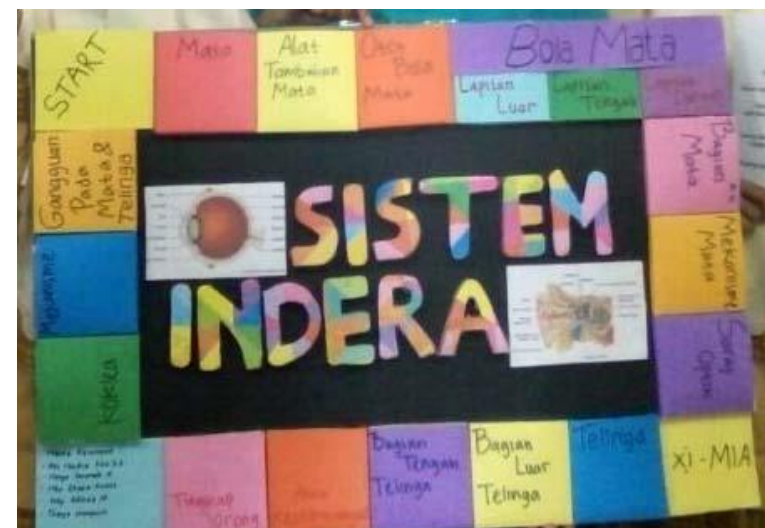

Figure 3: Monopoly game Learning Media with material of Sense of Sight (eye) and Hearing (ears) by Group III

Learning media by Group IV is in the form of 3D media themed story building on sensory system (nose, skin and tongue) as shown in Figure 4.

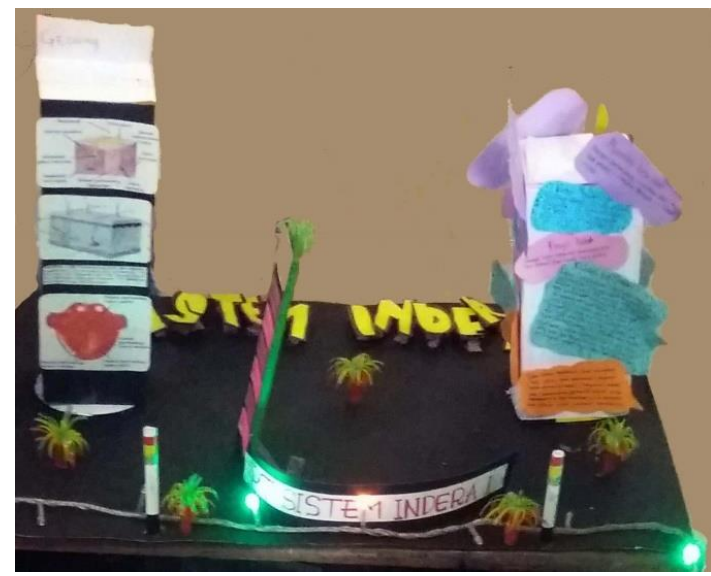

Figure 4: 3D Multi-level building Media of Sense System of Smell (Nose), Touch (Skin), and Taste (Tongue) material by Group IV

The results of students' creative thinking skills are assessed based on indicators of aspects of originality, ability to create a 
unique idea on making learning media about the system of coordination system is shown in Table 2.

\section{TABLE II. ASSESSMENT OF ORIGINALITY IN MAKING MEDIA} LEARNING

\begin{tabular}{|c|c|c|}
\hline Group & Score & Category \\
\hline I & 75 & Unique \\
\hline II & 85 & very Unique \\
\hline III & 92 & very Unique \\
\hline SIV & 87 & very Unique \\
\hline
\end{tabular}

Information :

score 81-100 : a very unique idea

score 61-80 : a unique idea

score 40-59 : a pretty unique idea

score 20-39 : a less unique ideas

score 0-19 : non-unique idea

The average score of students' creative thinking on originality aspects is 84.75 which is categorized as very unique. Creative thinking based on criteria including the level of creative thinking is categorized in very high level as shown in Table 3.

\section{TABLE III. CRITERIA OF CREATIVE THINKING SKILLS LEVEL [9]}

\begin{tabular}{|c|c|c|}
\hline Group & Percentage (\%) & criteria \\
\hline I & 75 & High \\
\hline II & 85 & Very High \\
\hline III & 92 & Very High \\
\hline IV & 87 & Very High \\
\hline
\end{tabular}

\section{DISCUSSION}

The average score on the assessment of students creative thinking on originality aspects is 84.75 with a very unique category and falls to very high criteria. This suggests that coordinate system based on metacognitive strategies of selfplanning can train the creative thinking skills of students in accordance with the i.e a propose by Shannon and College [7] who teaches the use of metacognitive strategies to make students more successful as it can help them to direct their own learning. Furthermore, Hargrove [3] revealed that using some metacognitive strategies can help develop students' thinking skills, build metacognitive skills and their creative thinking.

Metacognitive strategies of self-planning can be used by students to design learning strategies of learning, one of which making mind mapping to estimate the time required to complete the learning task. It can train skills of originality thinking, i.e. to create new and unique ideas in creating a learning medium to create an original work. Learning media produced by students with a very creative category averages include 2D media in the form of posters, 3D media in the form of playgrounds, monopoly games, and multi-level buildings

\section{CONCLUSION}

The average score on the assessment of students' creative thinking on originality aspect is 84.75 with a very unique category and including the level of creative thinking with very high criteria. Learning on the material of coordination system by using metacognitive strategies can train creative thinking skills of students in making learning media.

\section{REFERENCES}

[1] Z. Arifin, Use of Information Communication and Technology in Education: Preparing for the 21st century Pages, Curriculum Development Program, Bandung: UPI Bandung, 2013.

[2] J. R. Fraenkel and N. E. Wallen, How to Design and Evaluate Research in Education, New York: McGraw-Hill, 2008.

[3] R. A. Hargrove, Creating creativity in the design studios: Assessing the impact of metacognitive skill development on creative abilities, (Doctoral dissertation), North Carolina State University, 2007.

[4] N. Hidayati, "Development of Student Activity Sheet Material Nervous System, Senses, and hormones", Saintifika, vol. 17, no. 2, pp. 1-9, 2015.

[5] H. N. Ibe, "Metacognitive strategy on classroom participation and student achievement in senior secondary school classrooms scence", Science Education International, vol. 20, no. 1-2, pp. 25-31, 2009.

[6] R. D. Son, Y. Rinanto, S. Dwiastuti, and I. Irfa'i, "The Increasing of Students Creative Thinking Ability Through of Inquiry Learning on Students at Grade XI MIA of SMA Negeri 1 Karanganyar Colomadu in Academic Year 2015/2016", Proceeding Biology Education Conference, 2016, pp. 330-334.

[7] S. V. Shanon and W. S. College, "Using metacognitive strategies and learning styles to create a self-directed learners", Institute for Learning Styles Journal, vol. 1, pp. 14-28, 2008.

[8] C. Y. Shen and H. C. Liu, "Metacognitive Skills Development: A WebBased Approach in Higher Education", The Turkish Journal of Educational Technology, vol. 10, no. 2, pp. 140-150, 2011.

[9] F. N. Sugiyanto, M. Masykuri, and Muzzazinah, "Analysis of Senior High School Student's Creative Thingking Skills Profile in Klaten Regency", Journal of Physics, pp. 1-5, 2018.

[10] E. Susantini, S. Indana, and Isnawati, "Using Metacognitive Strategy to Teach Learning Strategies: A Study of Indonesian Pre-Service Biology Teachers", The New Educational Review , pp. 258-268, 2018.

[11] E. Susantini, S. B. Sumitro, and H. Susilo, "Improving learning process in genetics classroom by using metacognitive strategy", Asia Pacific Education Review, vol. 19, no. 3, pp. 401-411, 2018.

[12] Yusnaeni, A. D. Corebima, H. Susilo, and S. Zubaidah, "Creative Thinking of Low Academic Student Search Solve Undergoing Create and Share with metacognitive Integrated Learning Strategy", International Journal of Instruction, vol. 10, no. 2, pp. 245-262, 2017.. 